\title{
Hän ja muut: väitöskirja pronomineista ja ihmisistä
}

KATRI PrIIKI: Hän, se, tää vai toi? Vuorovaikutussosiolingvistinen tutkimus henkilöviittauksista Kaakkois-Satakunnan nykypuhekielessä. Turun yliopiston julkaisuja, sarja C, osa 432. Scripta Lingua Fennica Edita. Turku 2017. $90+124$ sivua.

Pronominit ovat kielen ja kommunikaation ydin. Niillä voi viitata mihin tahansa keskustelumaailmassa olemassa olevaan referenttiin, ja näin ne heijastavat laajinta luokittelua, mikä meillä maailmasta on. Pronominit sekä kuvaavat että myös luovat referenttejä, ja pronominivalinnalla keskustelijat pystyvät hahmottamaan kontekstin pääpiirteitä. Kielet eroavat toisistaan kuitenkin sekä pronominien määrän että käytön suhteen. Suomen kielessä on kolme demonstratiivivartaloa (tämä, se ja tuo) ja persoonapronomini hän, jotka muodostavat yhdessä kolmannen persoonan henkilöviittausten rungon. Ne ovat mielenkiintoisia sekä suomen kielen käytön kannalta että typologisesta näkökulmasta. Ei siis ihme, että pronominit ovat olleet fennistiikassa jatkuvasti esillä. Katri Priikin Turun yliopistoon tekemä väitöskirja lisää aiheeseen kuitenkin paljon uutta monestakin näkökulmasta, mitä esittelen seuraavassa.

\section{Tutkimusaihe ja-metodi}

Katri Priiki määrittelee tutkimuksensa metodiksi vuorovaikutussosiolingvistiikan, joka tarkoittaa, että perinteisempi 1960-luvulla syntynyt sosiolingvistiikka on yhdistetty suomalaisessa kielitieteessä jo melkein yhtä perinteiseksi muodostuneeseen vuorovaikutuksen tutkimukseen. Sosiolingvistiikkaa pidetään yleensä kielellisen variaation tutkimuksena. Variaatio voidaan nähdä monella eri tavalla, yleensä kuitenkin kytkettynä puhujien ikään, sukupuoleen, sivistystasoon tai puhetilanteen ominaisuuksiin. Priikin väitöskirjassa on kyseessä yhden alueen - Kaakkois-Satakunnan - puhekieli, mikä on tutkimusaiheen kannalta tärkeää siinä mielessä, että juuri Satakunnassa on myös kansakielessä käytetty hän-pronominia. Tämän seudun 
puheessa hän-pronominin käyttö ei siis ole vain kirjakielen vaikutusta kuten joissakin muissa Suomen murteissa. Määräiseen henkilöön viitattaessa tällä alueella on neljä mahdollista pronominia: kolme demonstratiivia eli se, tämä (yleensä lyhyessä muodossa tää) ja tuo (yleensä muodossa toi) sekä persoonapronomini hän. Näiden neljän vaihtoehdon käyttöä Priiki tarkastelee sekä puhujaryhmät että eri tilanteet huomioon ottaen.

Väitöskirjan menetelmissä on paljon uutta. Aineistona on käytetty Satakuntalaisuus puheessa -hankkeen puitteissa kerättyjä keskusteluja. Hän-, tää-, se- ja toi-esiintymät on koottu tietokantaan, mikä on antanut mahdollisuuden tilastollisten menetelmien (päätöspuut ja satunnaismetsät) käyttöön. Toisaalta sama aineisto on sopinut myös laadulliseen keskustelunanalyysiin. Joitakin tutkimuskysymyksiä (pääasiassa hän-pronominin kohteliaisuuteen liittyvää käyttöä) Priiki tarkastelee myös kyselytutkimusten avulla kansanlingvistisestä näkökulmasta. Näin on syntynyt ainutlaatuinen yhdistelmä määrällisiä ja laadullisia menetelmiä, joka erottaa tämän tutkimuksen aikaisemmista, pääosin keskustelun laadulliseen tutkimukseen pohjautuvista tutkimuksista (esim. Laury 1997, Seppänen 1998, Etelämäki 2006). Ihan uutta laadullisten ja määrällisten menetelmien yhdistäminen ei tietenkään ole (ks. esimerkiksi Lappalainen 2004), mutta tilastolliset menetelmät ovat kehittyneet viime vuosikymmenillä nopeaa vauhtia, mikä on antanut paljon uusia mahdollisuuksia.

\section{Väitöskirjan artikkelit}

Väitöskirja koostuu viidestä aikaisemmin julkaistusta artikkelista ja johdantoluvusta. Artikkelit ovat perusteellisesti suunniteltuja ja muodostavat hyvän kokonaisuuden. Johdantoluvussa esitetään perusteellisesti teoreettinen tausta ja kootaan tulokset.

Artikkeli "Antagonistin äänellä" on kvalitatiivinen tutkimus yhdestä keskustelusta. Se eroaa metodologisesti hyvin paljon muista artikkeleista, mutta muodostaa kuitenkin selkeän lähtökohdan koko väitöskirjalle: pronominivaihtelulla ilmaistaan arkikeskustelussa monenlaista, ja seuraavien artikkelien tehtäväksi jää selvittää asiaa kvantitatiivisilla metodeilla tarkemmin. Priiki analysoi, miten ja miksi kertoja viittaa erittäin usein hän-pronominilla samaan henkilöön, entiseen poikaystäväänsä. Hän-pronominin tehtävänä tässä valituskertomuksessa on esittää puhujan ironista suhtautumista referenttiin, koska muihin henkilöihin viitataan se-pronominilla. Tällainen funktio alun perin logoforiselle hän-pronominille näyttää syntyneen referointitilanteissa, joissa kuulopuhe yhdistyy vähättelyyn. Priiki näyttää selvästi, miten kertomuksessa yhdistyvät toisaalta kerronnan kulku ja suora referointi kerronnan osana, toisaalta kertomuksen tapahtumien ja kertomuksen avulla tilanteeseen tuodun antagonistin evaluaatio.

Artikkelin "Kaakkois-Satakunnan henkilöviitteiset hän, se, tää ja toi subjekteina" tavoite on käyttää kvantitatiivisia menetelmiä siihen, mihin kvalitatiiviset menetelmät eivät pysty: näyttämään, miten pronomininvalintaan vaikuttavat edellinen viittaus, lauseenjäsenfunktio, verbityyppi ym. Uutena näkökulmana Priiki nostaa esiin virittyneisyyden pronomininvalinnan kriteerinä: aineisto osoittaa, että jos referenttiin on viitattu pronominilla kerran, siihen todennäköisesti viitataan samalla pronominilla myös seuraavan kerran. Kolme neljästä tutkitusta pronominista osoittaa taipumusta ketjuuntumiseen; vain tää ei yleensä muodosta viittausketjuja. Hän ja se ovat subjekteja useammin kuin tää ja toi, mikä osoittaa taas kerran, että se-pronominin käyttö muistuttaa persoonapronomineja. Suurin yllätys on kuitenkin, kuten myös kirjoittaja toteaa, että hän-pronomini ei leviä logoforisesta kontekstista päälauseeseen puheaktiverbien 
tapauksessa. Näyttää siis siltä, että epäsuora puhe tarvitsee voimakkaan pronomini-indeksin, jota ei voi "laimentaa" käyttämällä samaa pronominia johtolauseessa.

Artikkeli "Se oli iha hullu se hammaslääkäri. Kaakkois-Satakunnan henkilöviitteiset se, hän, tää ja toi eteenpäin lohkeavan konstruktion osina ja ensimainintoina" käsittelee eteenpäin lohkeavaa konstruktiota (esimerkiksi se oli iha hullu se hammaslääkäri tai kyl se on aika sitkee tää tein Karri kans) ja sen osana olevia pronomineja. Artikkelissa annetaan lohkeamakonstruktiolle perusteellinen määritelmä, jollaista ei tähän asti tällä tarkkuudella ole tietääkseni esitetty. Tarkka määrittely puolestaan mahdollistaa aineiston tilastollisen analyysin, joka osoittaa taas kerran, että se ja hän käyttäytyvät eri tavalla kuin tää ja toi. Priiki tuo selvästi esille sen, että lohkeamakonstruktiot eivät ole keskustelutilanteessa virheitä vaan yksi tapa viitata mm. uusiin referentteihin. Vahvasti demonstratiiviset tää ja toi sopivat hyvin siihen tehtävään.

Artikkeli "Henkilöviitteisten kolmaspersoonaisten pronominien vaihtelu Satakunnan nykypuhekielessä keskustelukumppanin tuttuuden mukaan" käsittelee samaa aineistoa siitä näkökulmasta, onko nauhoitustilanteessa mukana henkilö (eli nauhoittaja), jota kaikki eivät tunne. Samalla tarkastellaan myös pronominien ja puhujien iän korrelaatiota. Mielenkiintoisena sivutuloksena selviää, että vanhemmilla puhujilla on enemmän tää ja toi-pronominia. Tärkein tulos on kuitenkin se, että hän-pronominia käytetään kaikissa ikäryhmissä enemmän, jos läsnä on vieras ihminen. Tämän ilmiön syynä on kohteliaisuusperiaate, jota tässä artikkelissa on käsitelty arkielämässä vallitsevan kohteliaisuuskäsityksen mukaan. Näyttää siltä, että tuntemattoman kanssa puhuminen vaatisi aina kohteliasta puhetapaa, johon kuuluu kirjakielinen hän-pronomini. Artikkelissa käytetään myös kielenpuhujille tehdyn kyselyn tuloksia. Niistä tärkeänä piirteenä nousee esiin tiedostamattomuus. Kaikkia kielen piirteitä ei tiedosteta samalla tavalla. Esimerkiksi hän-pronominista tiedetään hyvin sen kuuluminen kirjakieleen ja "kohteliaaseen" puhetapaan, mutta kyselyyn vastanneet eivät olleet tietoisia sen logoforisesta funktiosta.

Artikkeli "Puhutun suomen kielioppia ja yksilöllistä vaihtelua. Kvantitatiivinen tutkimus hän-pronominista Kaakkois-Satakunnan nykypuhekielessä" kokoaa kaikki aikaisemmissa artikkeleissa käytetyt muuttujat yhteen ja analysoi niitä kvantitatiivisesti satunnaismetsämenetelmän avulla. Satunnaismetsät eivät kielitieteessä ole vielä kovin tavallinen tutkimusmenetelmä, mutta kirjoittaja on selvinnyt hyvin metodin esittelystä myös "maallikkolukijalle". Aikaisempien tutkimusten perusteella on aika odotuksenmukaista, että logoforisuus osoittautui kaikkein parhaiten se- ja hän-pronominin vaihtelua selittäväksi ilmiöksi, mutta uutta on se, että virittyneisyys on melkein yhtä tärkeää. Artikkelin tärkein osa kuvailee kuitenkin yksilöllisiä eroja, niin sanottuja puhujaprofiileja. Käy ilmi, että tää- ja toi-pronomineja on huomattavasti enemmän vanhemmilla puhujilla, kun nuorilla niitä korvaa se. Toisaalta logoforisuuden heikko tiedostaminen näyttää olevan yhteistä eri puhujaryhmille. Näkyykö siinä suomen kolmivartaloisen demonstratiivijärjestelmän lopun alku? Toivottavasti ei. Onhan pidettävä mielessä, että tämä tutkimus käsittelee vain henkilöviitteisiä pronomineja eikä koko demonstratiivijärjestelmää.

\section{Tuloksia ja pohdintoja}

Väitöskirjan johdanto-osa tarjoaa teoreettisen johdatuksen ja kokoaa väitöskirjan tulokset yhteen. Suomen pronominijärjestelmän kannalta tutkimuksessa on saatu uusia tietoja jokaisesta pronominista. Johdanto-osan luvussa 5 tulokset on koottu pronomineittain erittäin onnistuneesti. Se on yleisin ja neutraalein henkilöviitteinen pronomini, hän-pronominia käytetään 
usein samanlaisissa anaforisissa konteksteissa, mutta tunnusmerkillisenä joko logoforisesti, ironisesti tai kohteliaasti. Tää ja toi ovat paljon vähemmän frekventtejä; ne esiintyvät pääosin ensimainintoina ja eteenpäin lohkeavien konstruktioiden pronominiosana. Tää viitaa uuteen referenttiin, jota puhuja määrittelee ja nostaa esiin, toi viittaa taas vähemmän keskeiseen referenttiin, joka löytyy sekä puhujan että vastaajan huomiopiirin ulkopuolelta.

Priikin aineistosta nousee useita yleisteoreettisesti kiinnostavia aiheita. Suomen kielen ainutlaatuinen pronominijärjestelmä vie eteenpäin tutkimuksia siitä, mitä pronomineilla pystyy puheessa tekemään. Kun aihe on rajattu poissaoleviin henkilöihin, suuri osa pronominien käyttökonteksteista jää kuitenkin tarkastelun ulkopuolelle. Toisaalta aineisto on rajattu yksiköllisiin referentteihin. Vaikka se on väitöskirjan kokonaisuuden kannalta ymmärrettävää, on monikkomuotojen sivuuttaminen hieman harmillista, koska on mahdollista, että monikolliset pronominit käyttäytyvät eri lailla.

Suomen demonstratiivijärjestelmän rinnalla väitöskirja tuo esiin myös muita yleisteoreettisesti mielenkiintoisia aiheita. Yksi niistä on varmasti logoforisuus kategoriana. Priiki on kehittänyt logoforisuuden jatkumon (kuviona johdanto-osan s. 46), jonka avulla pystyy selittämään hän-pronominin käyttöä. Sopisiko se myös muihin kieliin, joissa on logoforinen pronomini? Väitöskirjassa on esitetty itsestään selvänä, että toisaalta tää ja tämä ja toisaalta toi ja tuo ovat saman pronominin muotoja. Voisiko sitä kuitenkin kyseenalaistaa? Kun kerran kyseessä ovat niin frekventit kielenyksiköt, voivatko jopa eri variantit ja niiden muodot käyttäytyä eri tavalla? Kielen käytön kannalta hyvin tärkeä aihe on myös kohteliaisuus. Mitä kohteliaisuus ylipäänsä on, kun samalla hän-pronominilla voi olla kohtelias virallisessa ympäristössä ja pilkata epävirallisessa? Edelleen, kun väitöskirja tarkastelee henkilöviittauksia, päästäänkö sen kautta lähemmäs myös sitä, mitä toinen ihminen meille on? Priikin väitöskirja on siis kokonaisuutena juuri sellaista arvokasta lajia, joka sekä vastaa että kysyy.

Renate Pajusalu

renate.pajusalu@ut.ee

Tarton Yliopisto,

Ülikooli 18, Tartu 50090, Viro

\section{Lähteet}

ETELÄMÄKI, MARJA 2006: Toiminta ja tarkoite. Tutkimus suomen pronominista tämä. SKS, Helsinki. LapPalainen, HanNa 2004: Variaatio ja sen funktiot. Erään sosiaalisen verkoston jäsenten kielellisen variaation ja vuorovaikutuksen tarkastelua. SKS, Helsinki.

Laury, Ritva 1997: Demonstratives in interaction. The emergence of a definite article in Finnish. John Benjamins Publishing Company, Amsterdam.

Seppänen, Eeva-LeEna 1998: Läsnäolon pronominit. Tämä, tuo, se ja hän viittaamassa keskustelun osallistujaan. SKS, Helsinki. 